\title{
THE SHOPPERS; VENUE SHOPPING, ASYLUM SHOPPING: A RESOLUTION IN EURODAC?
}

\author{
Catherine Odorige ${ }^{1}$
}

\begin{abstract}
The term shopping used in reference to two strictly legal/politically somewhat related issues 'Asylum shopping' and 'Venue shopping', belong to two different spheres of actors. Asylum shopping is descriptive of the action of asylum seekers selectivity, in choice of member state where they perceive better social and welfare conditions. Venue shopping, a concept introduced by Guiraudon in 2000, explain the action of movement by member states in the European Union from venues of national jurisdiction, less amenable to their search for more restrictive migration policy to venues howbeit transnational like transit countries and EU institutions suitable for their policy perspectives. This they did for the primary purpose of avoiding adversary activities of non-state actors and the judicial scrutiny within their national sphere. Common European Asylum System (CEAS) the Dublin Directive and the EURODAC are spill-over in the European integration Project, commonly referred to as the Schengen acquis in the area of migration and integration of third country nationals. The three directives are the results of policy search to administer the entrance and residence of third country nationals especially in the area of irregular migration.
\end{abstract}

This paper seeks to examine the inter-relationship between the two actors to which the commercial term shopping describes, how an electronic regulation in EURODAC became a check to their 'shopping.' For the asylum seekers exposing their agency, for the member states reducing anxieties, and influenced the ceding of powers hitherto held by member states through (intergovernmental) negotiations to the EU (Supranational) and the impact of these policy measures in checking security challenges and sanitization of this angle of asylum administration in the EU.

\section{Introduction}

The new political community, which is the result of a borderless EU, a regional system of governance totally at variance with the known systems, dramatically challenged by the establishment of the supranational context in the Treaty of the European Union TEU in 1993 (Wiener 1998 p 4). Since its creation, members of the political community have been in constant search on how to manage challenges that has arisen because of the alliance. Immigration and asylum administration has been on the top agenda because of the removal of security checks at border points where possible external security challenges to the member states are detected. Scholars have attributed the anxiety of member states to the fact that immigration belong to an area of national interest regarded as high politics which relates to the sovereignty of the state (Hoofmann 1965). The 'opt out' and 'opt in' options under the EC treaty agreements reached during the intergovernmental conference of 1996/1997 (Peers 2000; Monar 1998) has enabled countries to choose the extent to which they can participate in certain areas of the Schengen acquis. Both the UK and Irish governments opt out of the Schengen arrangement and still apply border controls at their borders extending to EU citizens. Denmark participate in the Schengen arrangement but opt out of

\footnotetext{
${ }^{1}$ National University of Public Service Budapest.
} 
the title IV of the EC treaty which makes her participation in the community decisions in the field of asylum and immigration dependent on its classically related to the Schengen acquis.

States asylum and immigration policies have characteristically been restrictive to try to keep out unwanted immigrants from their territory, even in cases of those deserving international protection, which is a provision, made for in the 1951 convention and its 1967 protocol to which member states are signatories. States have overtime avoided the confinement of migration policy to a single national ministry because of its transversal character having implications for range of policy areas like labour economics, foreign and social affairs especially as it relates to admittance and residence of non-citizens (Guiraudon 2000). Criticism on the restrictive policies of member states that undermine the protection of asylum seekers by pro migrants NGO (Freeman 1998; Joppke 1998) is the reasons states in the European Union began to favour cooperation on asylum and migration at the EU level. So called in scholarly literature 'Venue Shopping' which refers to the seeking of new venues by policy makers when encountering difficulties in their traditional policy venue, obstacles to developing stricter migration policies led to the EU level cooperation (Guiraudon 2000, 2003). Member states found a safe haven at the EU level to circumvent domestic obstacles to achieving policy choices on migration (Maurer \& Parkes 2007 Lavenex 2006). The venues keep shifting depending on what best suits the interest of the policy makers intergovernmentalist approach or supranational as well as the use of transit countries to manage their migration challenge. The development of the European Union asylum and migration policy, despite the fact that these are related but different policy issues, the main aim is to find ways to keep immigrants out of the EU. (Boswell, 2003, 2007, 2008; Ellermann, 2008; Geddes, 2000; Guild 2004; Lavenex, 1998, 1999, 2001a, 2006; Levy 2005 Thielemann, 2001a, 2006). The cooperation in such field of asylum led to the Common European and Asylum System, which experienced a storm in the wake of the migration, flows in the in 2015. The CEAS determine which country has responsibility for asylum claim through the Dublin regulation, safe country concept, determining asylum claims is a complex procedure where in variety of legal procedures, implemented in individual member states. Regardless of CEAS, there is no uniformity in sight in the way member states determines who get recognition and who does not, or why there are not uniformed percentages in asylum recognition rates across member's states. An example is the report on asylum rates in the 2015/16 of asylum seekers from Syria Germany was 97.4/57.2 percentage while Hungary was 5.7/0.5 \% (Burmann \& Valeyatheepillay 2017). The differences in interpretation and policy, is determined by what the state perceives as convenient to for its local immigration and integration policy. Despite these various interpretations and implementations along common policy agendas, one area where there has been unanimity is the EURODAC where states, which have chosen to stay out of the Schengen acquis Britain /Ireland, and Denmark who opted out of CEAS as well as the Nordic countries, have been participating in EURODAC.

\section{Asylum and Asylum Shopping}

Asylum refers to the process by which a person who has lost protection of his state moves to another country to seek for protection. An offshoot of the Universal Declaration of human rights in 1948, the United Nations Convention relating to the granting of refugee status adopted in 1951, which gives recognition to the right of persons to seek asylum from persecution. This convention has been subjected to amendment only by the 1967 protocol, which removed the geographical limits of the 1951 convention (UNHCR). Asylum shopping, a negative connotation refers to asylum seekers perceived agency in choice of destination (Moore 2013). The application for asylum in more than one member state in the EU or chooses a member state over others because of perceived higher standard of reception conditions or social security assistance. (DG Home). The implication 
of this agency to policymaking is that it tends to undermine the European integration project to the extent of resulting in regulatory policy to check it. Despite the relevance of this discourse, to the asylum theorizing and administration not much is reflected in academic literature, as much is yet to be done to subject the rhetoric behind the discourse and the social political implication to academic perusal. Though widely acknowledged in the works of (Menz 2009; Muller 2004; Thomas 2003; Wilson 2006). (Moore 2013) represents the emergent academic research on the discourse, centred on the social-cultural meaning of asylum shopping, and how it is naturalised in the British media, so that in 2000 news on asylum and refugee issue were the dominated issues in the media. Asylum seekers were in the news represented as cheating the system, exploiting social resource and scrounging welfare state benefits and social housing. With the politicians and the press implying, that economic migration or more sinister claims were driving the migration (Moore 2013). Regular and irregular movements as possible ways to classify asylum /refugee movements (Jaeger 1988), classifies as 'irregular' movements by bona fide asylum seekers because the trip is made under duress. 'Irregular movements' he classifies as movement taken by asylum seekers and refugees after fleeing the country where persecution is feared and the patterns of these movements may not comply accurately to the international community expectations (Jaeger $1988 \mathrm{pp} 23-4)$. Of relevance to this discourse is the description of movements where asylum seekers move from one or more countries because the asylum seeker received neither protection nor asylum, to which Jaeger does not, considered as irregular. Irregular movement he avers as spontaneous, unauthorised, unscheduled arrival of protected asylum seeker or refugees. That is asylum seekers have received some form of protection in one country yet moves in an unauthorised or unscheduled way to another country. Pointing to difficulty in applying the concept of irregular movement due to the challenges of increasing problem of personal documentation, lack of solution to the problem of 'refugee in orbit' the divergent views between jurists, courts and states on such basic topics as 'asylum' and 'protection' (p 25). However, (Moore 2013) explains Jaeger mention of refugee in orbit in terms of his meaning asylum shopping but the refugee in orbit described by Jaeger, moved through the first country as a transit point without applying for asylum there. Which could be for a variety of reasons, ranging from fear of not receiving the refugee status, to possible better reception and welfare elsewhere other that country that is a closer neighbour to the country of his persecution. This has also brought about the controversial country of first asylum, the concept used to establish that some asylum determinations are someone else's business, i.e the countries that first harboured the claimant (Vierdag 1988). The hostilities toward the others mostly from post-colonial/imperial nations in Europe (Guilroy 2004, 2005) where the violent histories of post-colonial countries are hidden in hostilities towards those classified as racial other which include immigrants and asylum seekers who are unwanted because they are bearers of imperial and colonial past which these countries are bent or denying.

\section{Venue Shopping}

Several theories furthered to explain member states move form exclusivity control of migration and asylum in the early stages of the European integration project, a policy area tied to security and sovereignty, which states preferred to keep within their reach away from the jurisdiction of the supranational EU. Difficulty arising from spill over effects of the European integration project, explains this kind of selective policies by two schools of thought, the first stems from theories of international relations that due to globalization states seek international solutions to domestic problems (Keohane \& Nye 1989). Decreasing ability of the state to control immigration because of its self-preserving nature, the constraining impact of economic imperatives and international legal norms, and this view, linked to the neo-functionalist view that spillover and consequences from other EU pioneering policies provide the rationale for further common EU policies. The second is 
on the state centric intergovernmental view on immigration control, that growing international immigration and crime causes convergance for national preferences as a pre-condition for cooperation. Here the EU provide the framework for member states to cooperate to reducing external negatives and cost of transaction (Moravcsik 1993 and Hix \& Hoyland 2011). Spillover is broken down into functional spill-over, political spill-over and cultivated spill-over (Tranholm Mikkelson 1991). In addition, the point made in (Bierman et al 2009) contextual point of conventional wisdom which suggest that spillovers foster issue linkages and further integration. While acknowledging some of these theories Giraudon 2000 citing (Baumgartner \& Jones 1993) reference to policy venues analyses the internationalization of migration and asylum control policy as venue shopping. The institutional locations where policies reached through the mobilization of different constituencies, as political actors tend to seek policy venues that are suit their policy choices. Venue shopping emphasizes actor's strategies and the rule bound environment to which actors respond. Seeking new venues in order to adapt to institutional constraint framing processes to policy images the constructivist's moment (Guiraudon 2000). The reasons for the transcendence in policy avenues is first because they are relieved from the judicial constraint from national level, opposition from ministries, parliaments and migrants aid groups are miffed, finally the job of policing have been seconded to transit and sending countries as 'Sheriff deputies' (Torpey 1998).

The rise in asylum seekers in Europe in the 1990s led to the securitization of the issues of asylum (Bigo 1996). Asylum challenges like Asylum shopping and security migration policies experience new venues of its development through coordination via liberal intergovernmentalist approaches of supranational.

Venue shopping that bought the member states to seek international solutions to national challenges to policy implementation was also a relief for the EU, as it needed to foster partnering relationships with the member states especially in contentions issues like migration and asylum. That were major themes in political rhetoric discrediting the European integration project and political actors and the media were fuelling most of the disaffections (Moore 2013). Unfolding reaction to immigration and asylum is evident that countries that pushed for the single market framework in the European integration did not for see the spill over effects that will follow. Among which are the UK and Ireland opted out of EU migration discussions an obvious undermining of the inter-linkages between the two (Guiraudon 2000). The Europe a la carte in the Amsterdam treaty gave room for these opting out of the Schengen acquis and Denmark despite being a member of the Schengen cooperates only in the common visa policy and not the asylum policy. Iceland and Norway membership of the Nordic Passport Union are bound by the Schengen protocol, of the Amsterdam treaty. Neo functionalist theories explains the commission back seat role in the policy drafts acting only in maximizing outlook and agenda setting function (Pollack 1994), considered it wisdom to leave decisions in the these fields to the discretion of the member states in view of the stalemate hitherto experiences in these fields. Therefore, the searches for securitised administration of asylum were realised by the member states.

\subsection{Rationale behind EURODAC}

EURODAC. An acronym for European dactylographic system, an automated biometric identification allowing for instant and exact comparison of unique physiological features for individual's iris, face and finger print for law enforcement purposes (Aus 2006). The Refugee influx in Europe has put pressure on the member states and these developed and industrialised states look for varying means to constrain the influx, as a check against asylum abuse and 'asylum shopping' in an integrating Europe striving for a full-fledged harmonization of substantive and 
procedural refugee law (Aus, 2006). The EU started to develop a Common European Asylum System to improve the framework of the Convention relating to the status of refugees. Several common directives, established in alignment to member states legislation, procedural directive, reception condition directives, and qualification directives. Spill over effect of administering directives led to the development of the Dublin Regulation, which helped establish the state responsible for examining the asylum application, because controversies of country of first asylum and irregular movements (Vierdag 1988; Jaeger 1988) which can be antithetical to an asylum claim regardless of the merits of the case. In addition, the advantage of saving member States involved in the Common European Asylum directive, from conducting "one-to many checks" in this category, is the justification for involvement in the adoption of EURODAC by the Council of the European Union on 12/11/2000 and 02/28/2002 (Council 2000a; 2002). The two dates in the adoption of the Eurodac system is supportive of the argument by (Aus 2003) that securitization of the asylum and immigration policies in the European Union, was not the result of an 'external shock' of the September 112001 attack. However, internal institutional dynamics resulting in an imbalance between the principles of freedom security and justice are linked to the first. The first Eurodac directive was passed in 2000 prior to the 9/11 attack, only the second one which came later in 2002 extended to irregular border crossing, illegal residence and EU citizens, after the attack could be linked influences of the attack, providing additional window of opportunity supranational executions of powers. The biometric feature of Eurodac, which allows for immediate identification of unique physiological features, helps member state to determine if an asylum seeker has applied for asylum elsewhere in the European Union. Which is a check against the rate of asylum shopping; the knowledge that they are subject to detection has put a check on asylum seekers agency. The system has also been a security check for detecting terror attacks and criminal acts by individuals pretending to be asylum seekers.

\subsection{JHA; Justice and Home Affairs, Area of freedom Security and Justice}

The parallelism of the JHA department responsible for freedom security and justice, which takes responsibility for the protection of universal human rights and the right to privacy, being the initiator of the Eurodac regulations; which run contrary to the formal foundations of the department. The extension of the Eurodac database to irregular border-crossing, illegal residence of third country national and EU citizens this is illustrative of the fact that task expansion on European level and executive "fusion" may take place in practice (Aus 2003). Eurodac Regulation is framed as a Dublin-related measure in the field of asylum, passed on the legal basis of art. 63 (1) (a) of the EC Treaty in its currently valid "Nice" version (Ibid). This treaty provision authorizes the Justice and Home Affairs (JHA) Council to adopt Community legislation laying down "criteria and mechanisms for determining which Member State is responsible for considering an application for asylum" lodged in the European Union by a third country national, actors calculating strategy produces political outcomes adherent to the rationalist's logic of consequentiality, which may include supranational legislative acts as the EURODAC. In rationalist analytic framework, purposive-rational actors tend to perform means-end and end-ends calculations culminating in utility-maximizing choices (Aus 2003). Rationality is determined by action taken when the ends, means and secondary results are weighed and accounted for. This involves the rational consideration of alternative means to an end, of relationships to an end of secondary consequences and the importance of different possible ends (Elster 2000, cited in Aus 2003). The rationality in choices made by countries in Europe by the provision given in the a la carte to stay out of Common European Asylum system -Dublin, the Schengen acquis UK and Ireland. However, deciding to cooperate in the supranational structure of the EU in the EURODAC regulation attests to the merits ease of the regulation in the administration of third country national's entre, stay and securitisation 
of the target group for ease of policing and asylum administration. (Geddes 2005) however points to the their opt in decision as being at variance with the justification for EURODAC which is tied to the article 61 EC the elimination of border checks to which these countries opted out of. It is allegedly addressing challenges of irregular or secondary movements where it was simply impossible to identify persons, especially asylum shoppers bent on hiding their real identity (Aus 2003).

\section{Conclusion}

Rational choices of actors' action as it relates to end-means determine actor's decisions. EURODAC electronic features have impacted in no small measure in checking asylum shopping and the security implications of admitting third country nationals in view of the terror anxieties sweeping across the globe. Its advantages for asylum administration are evident in the general acceptance across member's states. Countries like United Kingdom and Ireland who had opted out of the Schengen acquis and Denmark which cooperate in the common visa policy and opt out of the CEAS regardless of being in the Schengen system have all opted in to the EURODAC as a means of checking asylum shopping and also because of the securitarian privilege it offers in the monitoring of third country nationals.

Sociological institutionalists' perspectives challenge the logic of appropriateness, (Olsen 2007) as a common good solution to pressing challenges applied by institutional actors. A closer observation reveals that this logic accounts for political attitudes and behavioural traits of institutional members pursuing other agendas (Arendt 1994). Meaning as appropriate as a logic of action might seem it may be a colour-blind device in the hand of political actors (Aus 2006). However the efficiency of its performance in the area of asylum applications is clear from the number of detections of asylum shoppers across EU member states. The Central Unit detected "asylum shoppers" -persons who lodged applications in more than one member state, 3100 persons between January 2003 to December 2004, these detections were mostly in countries like Germany, Sweden, France, the UK, and Austria (Aus 2003). On the other hand Eurodac have been less successful in illegal border crossing because of the delay by member states in the hotspots of irregular crossings to send information to the central processing unit in a suspicious attempt at undermining the Dublin II directive (Papadimitriou and Papageorgiou 2005). And discovery of second application asylum seekers attempts at defacing their fingers through cutting, burning so as not to be detected through their finger prints of having applied elsewhere for asylum. Finally the 'opt in' decision by hitherto opting out parties like the UK, Ireland and Nordic countries Iceland and Norway to participate in the Eurodac is because of the perception of the relative ease it brings in the face of the security and undermining challenges faced by EU member states in the asylum administration.

\section{Bibliography}

[1] ARENDT, H., Eichmann in Jerusalem. A Report on the Banality of Evil. Penguin. London 1994.

[2] AUS, J. P., Supranational Governance in an "Area of Freedom, Security and Justice", Eurodac and the Politics of Biometric Control, University of Sussex: Sussex European Institute, Working Paper No. 72. Sussex 2003

[3] AUS, J. P., EURODAC; A Solution Looking for a Problem? European International Online Paper, Vol 10 pp1-26. 2006 
[4] BAUMGARTNER, F., \& JONES, B., Agendas and Instability in American Politics, Chicago University Press. Chicago, 1993

[5] BIERMANN, F., PATtBerG, P., ASSELT, H., ZELLI, F., The Fragmentation of Global Governance Architecture: A Framework for Analysis. Global Environmental Politics 9, Massachusetts Institute of Technology. 2009.

[6] BIGO, D.,"Frontiers and Security in the European Union: The Illusion of Migration Control," In, Anderson, M. \& Bort, E., (eds.), The Frontiers of Europe, London: Pinter, pp. 148-164 1998.

[7] BOSWELL, C., 'The 'external dimension' of EU immigration and asylum policy', International Affairs, 79(3): 619-638 2003

[8] BOSWELL, C., Migration Control in Europe after 9/11: Explaining the absence of securitization', Journal of Common Market Studies, Vol.45, no.3, pp.589-610. 2007

[9] BOSWELL, C., Evasion, Reinterpretation and Decoupling: European Commission Responses to the 'External Dimension' of Immigration and Asylum', West European Politics, vol. 31, no. 3, pp. 491-512. 2008

[10] BURMAN, M., VAlEYATHEePILlAY, M., Asylum Recognition Rates in Top 5 EU countries https://www.cesifo-group.de/DocDL/dice-report-2017-2-burmann-valeyatheepillayjune.pdf 2017

[11] Council of the European Union "Council Regulation (EC) No 2725/2000 of 11 December 2000 concerning the establishment of 'Eurodac' for the comparison of fingerprints for the effective application of the Dublin Convention," in: Official Journal of the European Communities of December 15, 2000, Vol. L 316, pp. 1-10.

[12] ELSTER, J., Rationality, Economy, and Society,” in: Turner, S. (ed.), The Cambridge Companion to Weber, Cambridge University Press, pp. 21-41. 2000

[13] FREEMAN, G., The decline of sovereignty? Politics and immigration restriction in liberal states', in C. Joppke (ed.), Challenge to the Nation State: Immigration in Western Europe and the United States. Oxford University Press. pp. 86-108. Oxford 1998

[14] GEDDES, A. "Getting the Best of Both Worlds? Britain, the EU and Migration Policy," Oxford. International Affairs, Vol. 81, No. 4, pp. 723-740. 2005

[15] GEDDES, A., 'Lobbying for migrant inclusion in the European Union: new opportunities for transnational advocacy?' Journal of European Public Policy 7(4): 632-49. 2000b

[16] GUILD, E., Seeking asylum: stormy clouds between international commitments and EU legislative measures', European Law Review, vol.29 (2) April 2004.

[17] GUIRAUDON, V. "European Integration and Migration Policy: Vertical Policy-making as Venue Shopping," in: Journal of Common Market Studies, Vol. 38, (2) pp. 251-271. 2000 
[18] GUIRAUDON, V. "The Constitution of a European Immigration Policy Domain: A Political Sociology Approach," in: Journal of European Public Policy, Vol. 10, No. 2, pp. 263-282. 2003

[19] HIX, S., \& HOYLAND, B., The Political System of the European Union, third edition, Palgrave Macmillan. London. 2011.

[20] HOFFMANN, S., The State of War; Essays on the Theory and Practice of International Politics. Praeger Publishers. 1965.

[21] JAEGER, G., Irregular movements: the concept and possible solutions. In: Martin D (ed.) The New Asylum-seekers: Refugee Law in the 1980s. The Ninth Sokol Colloquium on International Law. Dordrecht, pp 23-48 Martinus Nijhoff . Netherlands 1988.

[22] JOPPKE, C., (ed) 'Challenge to the Nation-State: Immigration in Western Europe and the United States' Oxford University Press. Oxford. 1998.

[23] KEOHANE, R. O., NYE, J. S., Power and Interdependence. Second edition HarperCollins, London 1989.

[24] LAVANEX, S., The Europeanisation of Refugee Policies. Between Human Rights and Internal Security, Ashgate, Aldershot 2001.

[25] LEVY, C. (2005), 'The European Union after 9/11: the Demise of a Liberal Democratic Asylum Regime? Government and Opposition, pp. 26-59

[26] MAURER, A., \& PARKES, R., 'The prospects for policy-change in EU asylum policy: venue and image at the European level', European Journal of Migration and Law 9: 173-205 2007

[27] MENZ, G., The Neolibralized State and Migration Control: The Rise of Private Actors in the Enforcement and Design of Migration Policy. Debatte; Journal of Contemporary Central and Eastern Europe Vol. 17, 315-332, 2009.

[28] MOORE, K., Asylum Shopping in the Neo-Liberal social imaginary DOI: 101177/0163443712372090. SAGE. 2013

[29] MONAR, J., "Justice and Home Affairs in the Treaty of Amsterdam: Reform at the Price of Fragmentation," in: European Law Review, Vol. 23, No. 4, pp. 320-335 1998

[30] MORAVCSIK, A., Preferences and Power in the European Community: A liberal Intergovernmentalist Approach. Blackwell Limited. Oxford. 1993.

[31] MULLER, B., Globalization, security, paradox: towards a refugee biopolitics. Refuge Canada's Journal on refugees' vol. 22, Issue 1, 49-57. 2004

[32] OLSEN, P. O., Understanding Institutions and Logic of Appropriateness: Introductory Essay. ARENA Centre for European Studies, University of Oslo, 2007 
[33] PAPADIMItTIOU, P. N., \& PAPAGEORGIOU, I. F., “The New 'Dubliners': Implementation of European [sic!] Council Regulation 343/2003 (Dublin-II) by the Greek Authorities," in: Journal of Refugee Studies, Vol. 18, No. 3, pp. 299-318. 2005

[34] PEERS, S., Justice and Home Affairs: Decision-making After Amsterdam," in: European Law Review, Vol. 25, No. 2, pp. 183-191. 2000

[35] THOMSON, M., Images of Sangatte; Political Representations of Asylum-seeking in France and the UK. Sussex Migration Working Paper No. 18. Brighton: Sussex Centre for Migration Research, Sussex 2003

[36] THIELEMANN, E., 'The Soft Europeanisation of Migration Policy: European Integration and Domestic Policy Change', Paper prepared for the ECSA 7th Biennial International Conference, May 31 - June 02, 2001, Madison, Wisconsin 2001.

[37] THIELEMANN, E., the Effectiveness of Asylum Policy in Controlling Unwanted Migration, in Parsons C., \& Smeeding, T., (eds.) Immigration and the Transformation of Europe, pp. 442-72, Cambridge University Press, Cambridge 2006

[38] TORPEY, J., Coming and Going: On the State Monopolization of the Legitimate Means of Movement. American Sociology Association. DOI 10.1111/0735-2751.00055, vol 16, issue 3, Nov. 1998.

[39] TRANHOLM-MIKKELSON, J., Neo-functionalism: Obstinate or Obsolete? A Reappraisal in the Light of the New Dynamism of the EC. Millennium Journal of International Studies. Vol. 20 No pp 1-22. 1991

[40] UNHCR, Convention and Protocol Relating to the Status of Refugee http://www.unhcr.org/3b66c2aa10.pdf

[41] VIERDAG, E. W., The Country of First Asylum: Some European Aspects; In: Martin D (ed.) The New Asylum-seekers: Refugee Law in the 1980s. The Ninth Sokol Colloquium on International Law. Dordrecht, pp 73-84 The Netherlands. Martinus Nijhoff.

[42] WIISON, D., Biometrics, borders and the ideal suspect. In: Pickering S, Weber L and Wilson D (eds) Borders, Mobility and Technologies of Control. Springer, pp. 87-109, Netherlands 2006.

[43] WIENER, A., European Citizenship Practice; Building Institutions of a Non-State. Westview Press, Oxford 1998. 